\section{AJMT}

\section{Asia-Pacific Journal of Management and} Technology

Online ISSN: 2652-6840

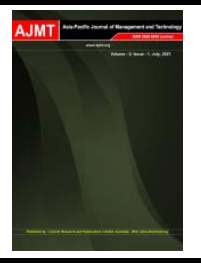

Original Article

\title{
Impact of Selected Stock Splits on Stock Performance in India
}

\section{Radha Vyas}

D. R. Patel \& R. B. Patel Commerce College \& Bhaniben C. Patel BBA College, Bharthana (Vesu), Surat Correspondence E-mail : radhanvyas@gmail.com

\begin{abstract}
Normally, investors perceive stock splits announcement in positive way. Hence, it becomes interesting phenomenon for many researchers. Thus, here, researcher has tried to study impact of selected stock splits on stock price performance in Indian stock market with reference to cumulative abnormal returns (CAR) and cumulative average abnormal returns (CAAR) by selecting 10 stock splits announced by BSE listed companies from different sectors during January 2021 to May 2021 period. The market model-event study methodology was used for the analysis. An event window of 81 days ( $t-40$ to $\left.t_{+40}\right)$ and estimation period of 30 days prior to stock splits announcements were used to investigate the market reaction. The findings of the analysis support the semi-strong form of efficient market hypothesis in Indian stock market.
\end{abstract}

Key Words: Stock Split; Market Model; Event Study; Event window; Stock price

\section{Introduction}

During last two years, Indian stock market has witnessed many swings. In COVID -19 pandemic during lock down many Indian people have started investment in Indian stock market due to future uncertainty. Moreover, to attract more investors companies also use different strategies like stock splits. This phenomenon has created interest in the mind of researcher to study impact of selected stock splits on stock prices in Indian stock market.

There are different literatures available in finance which explain about stock splits and positive abnormal returns following event announcement. The semi-strong form of efficient market hypothesis $(E M H)$ is one of the popular hypotheses used by earlier researcher and was also used in this study.

According to Fama, (1991) semi-strong tests are considered as event studies which measure how speedily stock prices react to corporate announcements of stock splits, dividend payments, merger, etc. As per semi-strong EMH, current market prices not only reflect historical price movements of stocks but also reflect all the information, which are publicly available about the companies.

\section{Review of Literature:}

Mishra, (2007) analysed the market reaction of stock splits on share price, stock return, trading volume and volatility from 1999 to 2005 in Indian stock market. He found a negative effect on share price and stock return of stock splits. The aggregate cumulative abnormal returns post split were negative in his study. According to his study, stock splits have decreased shareholders' wealth. No doubt, the results have shown positive effect on volatility and trading volume after the split events and suggested that split events improve liquidity in stock market. 
Chavali \& Zahid, (2011) conducted study for the BSE500 listed companies for the period of April 2006 to September 2008 with the objective to analyse the impact of stock splits on the stock price performance by selecting 20 stock splits from different industries. They used market model as event study methodology. They have selected event window of 81 days and estimation period of 30 days, 10 days prior to stock splits. They found positive market reaction

with significant positive average abnormal returns on $t_{0}$ and during $t_{-1}$ to $t_{+1}$. In addition, they confirmed the semi-strong form of efficient market hypothesis to be true in the Indian context.

Rohit, Pinto \& Bolar, (2016) in their study found a positive average abnormal return of $0.41 \%$ for stock split announcement and $0.58 \%$ for rights issue announcement from a sample of 90 announcements for stock splits and 29 announcements for rights issue during the period 2011-2014. They also reported that Positive Average Abnormal Returns were not statistically significant and confirmed that the Indian stock market is efficient in its semi-strong form.

Gupta \& Arya, (2020) conducted research with the objective to analyse impact of stock splits announced in India between 1999 and 2019 on stock returns with reference to stock split ratios. They have selected 224 splits and employed the standard event study methodology to find results. Average Abnormal Returns and Cumulative Average Abnormal Returns and z-test are used to analyse the impact on stock prices around the announcement day of splits. They chose window periods of 5 days, 10 days and 20 days around the event day. They found significant strong positive impact around the split announcement day for stock splits with 10:1 and 10:2 ratios.

Pal \& Parvathy, (2021) also studied the stock market reaction to stock split announcement of Nifty 100 Companies from 2015 to 2020 by using market-model event methodology for 21 days event window. They have calculated beta, abnormal returns, average abnormal returns and cumulative average abnormal returns. They have also used paired-t test 10 days prior and postsplit. They concluded that stock split announcements lead to negative abnormal returns.

\section{Methodology:}

\section{Objectives of the Study}

This study has been conducted to achieve the following objectives:

$>$ To examine the presence of abnormal returns on or surrounding stock splits announcement.

$>$ To test the significance of cumulative abnormal returns of selected companies.

$>$ To test the significance of cumulative average abnormal returns for selected companies.

\section{Hypotheses}

1 There is no significant impact of stock splits announcement on cumulative abnormal returns (CAR) of selected companies.

2 There is no significant impact of stock splits announcement on cumulative average abnormal returns (CAAR) of selected companies.

\section{Research Design}

For collecting data about share prices secondary data, websites of BSE and moneycontrol, have been used of the selected 10 companies which are listed on Bombay Stock Exchange (BSE) and announced stock splits during January 2021 to May 2021.

The current study uses the event study methodology, a standard methodology proposed by Fama et al., (1969) to examine the presence of abnormal returns due to the announcement. Market model is used to calculate the abnormal returns of securities. The $S \& P$ BSE SENSEX is the proxy for the market index.

The daily closing prices are considered for 81 trading days, 40 days prior to split, the share price on the A date to and also share prices of 40 trading days post the $A$ date. The event dates is defined as the announcement date of the stock splits. For developing market model 81 days event window, $\mathrm{t}-40$ to $\mathrm{t}+40$, where (event date) to is the stock split announcement date or A date is selected. For determining estimation period 30 trading days are chosen which end 10 days before announcement so as to avoid any effect of information leakage on stock prices. 
For analysis the abnormal returns (AR) for each of the stocks, the cumulative abnormal returns (CAR) and the cumulative average abnormal returns (CAAR) around the An date of stocks are calculated and t-test was applied to study impact of stock splits announcement on stock price performances.

Table 1: Sample Companies Details

\begin{tabular}{|c|c|c|c|}
\hline Company & Industry & $\begin{array}{c}\text { Event } \\
\text { (Announcement } \\
\text { Date) }\end{array}$ & $\begin{array}{c}\text { Split } \\
\text { Ratio }\end{array}$ \\
\hline SVP Global Ventures Ltd & Textiles & 14 January 2021 & $10: 1$ \\
\hline Bannari Amman Spinning Mills Ltd & Textiles & 12 February 2021 & $2: 1$ \\
\hline Trio Mercantile Trading Ltd & Financial Services & 09 March 2021 & $5: 1$ \\
\hline $\begin{array}{c}\text { Wardwizard Innovations \& Mobility } \\
\text { Ltd }\end{array}$ & Automobiles & 17 March 2021 & $10: 1$ \\
\hline Dixon Technologies (India) Ltd & Consumer Electronics & 18 March 2021 & $5: 1$ \\
\hline East West Holdings Ltd & Transportation - & Logistics & $5: 1$ \\
\hline Pritika Auto Industries Ltd & Other Industrial & 30 March 2021 & $5: 1$ \\
\hline Stylam Industries Limited & Forest Products & 12 April 2021 & $2: 1$ \\
\hline Finolex Industries Ltd & Plastic Products & 15 April 2021 & $5: 1$ \\
\hline Alkyl Amines Chemicals Ltd & Specialty Chemicals & 11 May 2021 & $2.5: 1$ \\
\hline
\end{tabular}

\section{Results:}

Table 2: $T$ Test for Cumulative Abnormal Returns (CAR)

\begin{tabular}{|c|c|c|c|c|}
\hline Company & Event Window & CAR & T stat & $\begin{array}{c}\text { Null Hypothesis } \\
\text { Test }\end{array}$ \\
\hline \multirow{8}{*}{$\begin{array}{l}\text { SVP Global } \\
\text { Ventures Ltd }\end{array}$} & $\mathrm{t}-40$ to $\mathrm{t}-21$ & 0.0300 & 0.3525 & Can't reject $\mathrm{H}_{0}$ \\
\hline & $\mathrm{t}_{-20}$ to $\mathrm{t}_{-1}$ & 0.3010 & 3.5374 & Reject $\mathrm{H}_{0}$ \\
\hline & $t_{-1}$ to $t_{0}$ & -2.1167 & -78.6570 & Can't reject $\mathrm{H}_{0}$ \\
\hline & $t_{0}$ to $t_{+1}$ & -2.1795 & -80.9897 & Can't reject $\mathrm{H}_{0}$ \\
\hline & $t_{-1}$ to $t_{+1}$ & -2.1701 & -65.8432 & Can't reject $\mathrm{H}_{0}$ \\
\hline & $t+2$ to $t+20$ & -0.3196 & -3.8530 & Can't reject $\mathrm{H}_{0}$ \\
\hline & $t+21$ to $t+40$ & -0.0317 & -0.3730 & Can't reject $\mathrm{H}_{0}$ \\
\hline & $t_{-40}$ to $t_{+40}$ & -2.1998 & -12.8448 & Can't reject $\mathrm{H}_{0}$ \\
\hline \multirow{9}{*}{$\begin{array}{l}\text { Bannari Amman } \\
\text { Spinning Mills Ltd }\end{array}$} & $\mathrm{t}-40$ to $\mathrm{t}-21$ & 0.0968 & 0.8602 & Can't reject $\mathrm{H}_{0}$ \\
\hline & $\mathrm{t}-20$ to $\mathrm{t}-1$ & -0.2392 & -2.1256 & Can't reject $\mathrm{H}_{0}$ \\
\hline & $t_{-1}$ to to & -0.6791 & -19.0852 & Can't reject $\mathrm{H}_{0}$ \\
\hline & to to $t_{+1}$ & -0.8190 & -23.0193 & Can't reject $\mathrm{H}_{0}$ \\
\hline & $t-1$ to $t_{+1}$ & -0.8088 & -18.5598 & Can't reject $\mathrm{H}_{0}$ \\
\hline & $t_{+2}$ to $t_{+20}$ & -0.2250 & -2.0520 & Can't reject $\mathrm{H}_{0}$ \\
\hline & $t+21$ to $t+40$ & -0.0647 & -0.5749 & Can't reject $\mathrm{H}_{0}$ \\
\hline & $t_{-40}$ to $t_{+40}$ & -1.2511 & -5.5254 & Can't reject $\mathrm{H}_{0}$ \\
\hline & $\mathrm{t}-40$ to $\mathrm{t}-21$ & 0.1344 & 0.9112 & Can't reject $\mathrm{H}_{0}$ \\
\hline
\end{tabular}


Asia-Pacific J.Mgmt. Tech. Volume 2(1) 38-43

\begin{tabular}{|c|c|c|c|c|}
\hline \multirow{7}{*}{$\begin{array}{l}\text { Trio Mercantile } \\
\text { Trading Ltd }\end{array}$} & $t-20$ to $t-1$ & 0.1113 & 0.7544 & Can't reject $\mathrm{H}_{0}$ \\
\hline & $t_{-1}$ to $t_{0}$ & -1.6250 & -34.8430 & Can't reject $\mathrm{H}_{0}$ \\
\hline & $t_{0}$ to $t_{+1}$ & -1.6725 & -35.8618 & Can't reject $\mathrm{H}_{0}$ \\
\hline & $t_{-1}$ to $t_{+1}$ & -1.6970 & -29.7093 & Can't reject $\mathrm{H}_{0}$ \\
\hline & $t_{+2}$ to $t_{+20}$ & -0.4669 & -3.2482 & Can't reject $\mathrm{H}_{0}$ \\
\hline & $t_{+21}$ to $t_{+40}$ & -0.2965 & -2.0103 & Can't reject $\mathrm{H}_{0}$ \\
\hline & $\mathrm{t}-40$ to $\mathrm{t}_{+40}$ & -2.1903 & -7.3796 & Can't reject $\mathrm{H}_{0}$ \\
\hline \multirow{8}{*}{$\begin{array}{l}\text { Wardwizard } \\
\text { Innovations \& } \\
\text { Mobility Ltd }\end{array}$} & $\mathrm{t}_{-40}$ to $\mathrm{t}-21$ & 0.1321 & 1.2345 & Can't reject $\mathrm{H}_{0}$ \\
\hline & $\mathrm{t}_{-20}$ to $\mathrm{t}_{-1}$ & -0.2553 & -2.3858 & Can't reject $\mathrm{H}_{0}$ \\
\hline & $\mathrm{t}_{-1}$ to $\mathrm{t}_{0}$ & -2.3782 & -70.2656 & Can't reject $\mathrm{H}_{0}$ \\
\hline & to to $t_{+1}$ & -2.3130 & -68.3396 & Can't reject $\mathrm{H}_{0}$ \\
\hline & $\mathrm{t}-1$ to $\mathrm{t}_{+1}$ & -2.3343 & -56.3131 & Can't reject $\mathrm{H}_{0}$ \\
\hline & $t_{+2}$ to $t_{+20}$ & -0.3446 & -3.3031 & Can't reject $\mathrm{H}_{0}$ \\
\hline & $t_{+21}$ to $t_{+40}$ & -0.3478 & -3.2496 & Can't reject $\mathrm{H}_{0}$ \\
\hline & $\mathrm{t}-40$ to $\mathrm{t}+40$ & -3.1286 & -14.5251 & Can't reject $\mathrm{H}_{0}$ \\
\hline \multirow{8}{*}{$\begin{array}{c}\text { Dixon } \\
\text { Technologies } \\
\text { (India) Ltd }\end{array}$} & $\mathrm{t}-40$ to $\mathrm{t}-21$ & 0.0139 & 0.8984 & Can't reject $\mathrm{H}_{0}$ \\
\hline & $t_{-20}$ to $t_{-1}$ & -0.0021 & 0.5279 & Can't reject $\mathrm{H}_{0}$ \\
\hline & $\mathrm{t}-1$ to $\mathrm{t}_{0}$ & -1.5773 & -103.6315 & Can't reject $\mathrm{H}_{0}$ \\
\hline & $t_{0}$ to $t_{+1}$ & -1.5610 & -105.0841 & Can't reject $\mathrm{H}_{0}$ \\
\hline & $t_{-1}$ to $t_{+1}$ & -1.5890 & -85.7154 & Can't reject $\mathrm{H}_{0}$ \\
\hline & $t+2$ to $t+20$ & -0.1547 & -5.7754 & Can't reject $\mathrm{H}_{0}$ \\
\hline & $t_{+21}$ to $t_{+40}$ & -0.1606 & -2.5412 & Can't reject $\mathrm{H}_{0}$ \\
\hline & $t_{-40}$ to $t_{+40}$ & -1.8645 & -19.8635 & Can't reject $\mathrm{H}_{0}$ \\
\hline \multirow{8}{*}{$\begin{array}{l}\text { East West } \\
\text { Holdings Ltd }\end{array}$} & $\mathrm{t}-40$ to $\mathrm{t}_{-21}$ & 0.1403 & 0.8454 & Can't reject $\mathrm{H}_{0}$ \\
\hline & $\mathrm{t}_{-20}$ to $\mathrm{t}_{-1}$ & -0.1521 & -0.9161 & Can't reject $\mathrm{H}_{0}$ \\
\hline & $\mathrm{t}_{-1}$ to $\mathrm{t}_{0}$ & -1.8035 & -34.3551 & Can't reject $\mathrm{H}_{0}$ \\
\hline & $t_{0}$ to $t_{+1}$ & -1.7537 & -33.4067 & Can't reject $\mathrm{H}_{0}$ \\
\hline & $t_{-1}$ to $t_{+1}$ & -1.7702 & -27.5341 & Can't reject $\mathrm{H}_{0}$ \\
\hline & $t+2$ to $t+20$ & -0.5110 & -3.1585 & Can't reject $\mathrm{H}_{0}$ \\
\hline & $t_{+21}$ to $t_{+40}$ & -0.2299 & -1.3847 & Can't reject $\mathrm{H}_{0}$ \\
\hline & $\mathrm{t}-40$ to $\mathrm{t}_{+40}$ & -2.5063 & -7.5023 & Can't reject $\mathrm{H}_{0}$ \\
\hline \multirow{8}{*}{$\begin{array}{l}\text { Pritika Auto } \\
\text { Industries Ltd }\end{array}$} & $\mathrm{t}-40$ to $\mathrm{t}-21$ & -0.0094 & -0.1249 & Can't reject $\mathrm{H}_{0}$ \\
\hline & $\mathrm{t}-20$ to $\mathrm{t}_{-1}$ & 0.0855 & 1.1308 & Can't reject $\mathrm{H}_{0}$ \\
\hline & $\mathrm{t}_{-1}$ to $\mathrm{t}_{0}$ & -1.6222 & -67.8247 & Can't reject $\mathrm{H}_{0}$ \\
\hline & to to $t_{+1}$ & -1.7427 & -72.8644 & Can't reject $\mathrm{H}_{0}$ \\
\hline & $t-1$ to $t+1$ & -1.7165 & -58.5984 & Can't reject $\mathrm{H}_{0}$ \\
\hline & $t_{+2}$ to $t_{+20}$ & -0.0875 & -1.1872 & Can't reject $\mathrm{H}_{0}$ \\
\hline & $\mathrm{t}+21$ to $\mathrm{t}+40$ & 0.3085 & 4.0795 & Reject $\mathrm{H}_{0}$ \\
\hline & $t_{-40}$ to $t_{+40}$ & -1.4456 & -9.4975 & Can't reject $\mathrm{H}_{0}$ \\
\hline \multirow{8}{*}{$\begin{array}{c}\text { Stylam Industries } \\
\text { Limited }\end{array}$} & $\mathrm{t}-40$ to $\mathrm{t}_{-21}$ & -0.0988 & -0.8462 & Can't reject $\mathrm{H}_{0}$ \\
\hline & $t_{-20}$ to $t_{-1}$ & 0.1437 & 1.2299 & Can't reject $\mathrm{H}_{0}$ \\
\hline & $\mathrm{t}_{-1}$ to $\mathrm{t}_{0}$ & -0.6775 & -18.3432 & Can't reject $\mathrm{H}_{0}$ \\
\hline & $t_{0}$ to $t_{+1}$ & -0.7067 & -19.1320 & Can't reject $\mathrm{H}_{0}$ \\
\hline & $\mathrm{t}-1$ to $\mathrm{t}_{+1}$ & -0.6631 & -14.6583 & Can't reject $\mathrm{H}_{0}$ \\
\hline & $t_{+2}$ to $t_{+20}$ & -0.1540 & -1.3524 & Can't reject $\mathrm{H}_{0}$ \\
\hline & $t+21$ to $t+40$ & -0.1935 & -1.6569 & Can't reject $\mathrm{H}_{0}$ \\
\hline & $\mathrm{t}-40$ to $\mathrm{t}+40$ & -1.0093 & -4.2940 & Can't reject $\mathrm{H}_{0}$ \\
\hline
\end{tabular}


Asia-Pacific J.Mgmt. Tech. Volume 2(1) 38-43

\begin{tabular}{|c|c|c|c|c|}
\hline \multirow{8}{*}{$\begin{array}{l}\text { Finolex Industries } \\
\text { Ltd }\end{array}$} & $\mathrm{t}-40$ to $\mathrm{t}-21$ & -0.0120 & -0.1521 & Can't reject $\mathrm{H}_{0}$ \\
\hline & $t_{-20}$ to $t_{-1}$ & 0.1663 & 2.1049 & Reject $\mathrm{H}_{0}$ \\
\hline & $t_{-1}$ to $t_{0}$ & -1.5556 & -62.2806 & Can't reject $\mathrm{H}_{0}$ \\
\hline & to to $t_{+1}$ & -1.5724 & -62.9536 & Can't reject $\mathrm{H}_{0}$ \\
\hline & $t_{-1}$ to $t_{+1}$ & -1.5500 & -50.6689 & Can't reject $\mathrm{H}_{0}$ \\
\hline & $t_{+2}$ to $t_{+20}$ & 0.0786 & 1.0213 & Can't reject $\mathrm{H}_{0}$ \\
\hline & $t_{+21}$ to $t_{+40}$ & 0.0956 & 1.2105 & Can't reject $\mathrm{H}_{0}$ \\
\hline & $t-40$ to $t_{+40}$ & -1.2439 & -7.8257 & Can't reject $\mathrm{H}_{0}$ \\
\hline \multirow{8}{*}{$\begin{array}{l}\text { Alkyl Amines } \\
\text { Chemicals Ltd }\end{array}$} & $\mathrm{t}-40$ to $\mathrm{t}-21$ & -0.0197 & -0.1818 & Can't reject $\mathrm{H}_{0}$ \\
\hline & $t_{-20}$ to $t_{-1}$ & 0.0805 & 0.7442 & Can't reject $\mathrm{H}_{0}$ \\
\hline & $t_{-1}$ to $t_{0}$ & -0.8305 & -24.2889 & Can't reject $\mathrm{H}_{0}$ \\
\hline & to to $t_{+1}$ & -0.7535 & -22.0347 & Can't reject $\mathrm{H}_{0}$ \\
\hline & $\mathrm{t}_{-1}$ to $\mathrm{t}_{+1}$ & -0.7600 & -18.1468 & Can't reject $\mathrm{H}_{0}$ \\
\hline & $t_{+2}$ to $t_{+20}$ & -0.3688 & -3.4991 & Can't reject $\mathrm{H}_{0}$ \\
\hline & $t+21$ to $t+40$ & -0.2322 & -2.1472 & Can't reject $\mathrm{H}_{0}$ \\
\hline & $t_{-40}$ to $t_{+40}$ & -1.2936 & -5.9447 & Can't reject $\mathrm{H}_{0}$ \\
\hline
\end{tabular}

Source: Author's Calculation

From the Table 2 it can be seen that the result is statistically significant at $5 \%$ level of significance only at 3 instances. For SVP Global Ventures Ltd during event window of $t_{-20}$ to $t_{-1}$, for Pritika Auto Industries Ltd during event window of $t_{+21}$ to $t_{+40}$ and in case of Finolex Industries Ltd, when there was event window of $t_{-20}$ to $t_{-1}$ was applied. It indicates that for all other event windows $T$ stat is statistically not significant at $5 \%$ level of significance and hence we fail to reject null hypothesis that there is no significant impact of stock splits announcement on cumulative abnormal returns (CAR) of selected companies. These results also support previous studies of semi-strong Efficient Market Hypothesis (EMH).

Table 3: $T$ Test for Cumulative Average Abnormal Returns (CAAR)

\begin{tabular}{|c|c|c|c|}
\hline Event Window & CAAR & T stat & Null Hypothesis Test \\
\hline $\mathrm{t}_{-40}$ to $\mathrm{t}-21$ & 0.0408 & 0.8984 & Can't reject $\mathrm{H}_{0}$ \\
\hline $\mathrm{t}-20$ to $\mathrm{t}-1$ & 0.0239 & 0.5279 & Can't reject $\mathrm{H}_{0}$ \\
\hline $\mathrm{t}-1$ to $\mathrm{t}_{0}$ & -1.4866 & -103.6315 & Can't reject $\mathrm{H}_{0}$ \\
\hline $\mathrm{t}_{0}$ to $\mathrm{t}_{+1}$ & -1.5074 & -105.0841 & Can't reject $\mathrm{H}_{0}$ \\
\hline $\mathrm{t}-1$ to $\mathrm{t}_{+1}$ & -1.5059 & -85.7154 & Can't reject $\mathrm{H}_{0}$ \\
\hline $\mathrm{t}+2$ to $\mathrm{t}+20$ & -0.2553 & -5.7754 & Can't reject $\mathrm{H}_{0}$ \\
\hline $\mathrm{t}+21$ to $\mathrm{t}_{+40}$ & -0.1153 & -2.5412 & Can't reject $\mathrm{H}_{0}$ \\
\hline $\mathrm{t}-40$ to $\mathrm{t}+40$ & -1.8133 & -19.8635 & Can't reject $\mathrm{H}_{0}$ \\
\hline
\end{tabular}

Source: Author's Calculation

From the above Table 3 it is clear that we fail to reject null hypothesis that there is no significant impact of stock splits announcement on cumulative average abnormal returns (CAAR) of selected companies, that means the results of all event windows are not statistically significant at $5 \%$ level of significance. It may be due to speed with which market absorb all information and these results also support semi-strong efficient Indian stock market.

\section{Discussion:}

The present study examines the announcement effect of the stock split on the Bombay Stock 
Exchange for the period January 2021 to May 2021. The study uses the market model event study methodology to find out abnormal returns (Fama, 1991). In many previous studies Average Abnormal Returns (ARR) are used but here, researcher has applied Cumulative Abnormal Returns (CAR) of selected companies and overall Cumulative Average Abnormal Returns (CAAR) for different 8 event windows. It is found out that there is no significant impact of stock splits announcement on cumulative abnormal returns (CAR) as well as Cumulative Average Abnormal Returns (CAAR) of selected companies (Chavali \& Zahid, 2011). The findings of the study are consistent with the findings of the past research done which give evidence to support the semistrong form of EMH in the context of Indian stock market (Mishra, 2007).

\section{Conclusion:}

The study concluded that the information regarding the corporate announcements of stock splits is absorbed quickly into the share prices and has a measurable impact on the stock price performance of the stock's splits. It is advisable for investors to consider other parameters too which affect share prices in addition to stock splits while taking investment decision.

\section{Acknowledgments:}

The authors would like to thank the funding authority or administration as applicable.

\section{Conflicts of Interest:}

The authors declare that the research review was conducted in the absence of any commercial or economic associations that could be construed as a potential conflict of interest.

\section{References:}

Chavali, K., \& Zahid, Z. (2011). Impact of stock splits on stock price performance of selected companies in Indian context. Afro-Asian Journal of Finance and Accounting, 2(3), 270-282.

Fama, E. F. (1991). Efficient capital markets II. The Journal of Finance, 46(5), 1575-1617.

Fama, E. F.,Fisher, L., Jensen, M., \& Roll, R. (1969). The adjustment of stock prices to new information. International Economic Review, 10(1)

Gupta, A., \& Arya, P. K. (2020). Impact of splits on stock splits ratios around announcement day: empirical evidence from India. Investment Management \& Financial Innovations, 17(3), 345.

Mishra, A. K. (2007). The market reaction to stock splits-Evidence from India. International Journal of Theoretical and Applied Finance, 10(02), 251-271.

Pal, P. \& Parvathy, V.K. (2021). Stock Splits Announcement Effect on Share Prices: Evidence from Nifty 100 Companies. CLEAR International Journal of Research in Commerce \& Management, 12(3), 22-26.

Rohit, B., Pinto, P., \& Bolar, S. (2016). Impact of stock splits and rights issue announcements on market price: Evidence from India. Drishtikon: A Management Journal, 7(2), 1-16. 